Sмiтh, H. \& Tempest, D. W. (1957). J. gen. Microbiol. 17, 731-738

\title{
The Uptake of Amino Acids During the Terminal Bacteraemia in Guinea Pigs Infected with Bacillus anthracis
}

\author{
By H. SMITH AND D. W. TEMPEST \\ Microbiological Research Establishment, Porton, Wiltshire
}

SUMMARY: As part of an attempt to study the metabolism of Bacillus anthracis in vivo and its connexion with virulence, the utilization of amino acids by this pathogen was examined whilst it was growing in the blood of guinea pigs during the terminal phases of anthrax. Under these conditions, $\boldsymbol{B}$. anthracis used relatively large quantities of glutamine, threonine, tryptophan and glycine, whereas histidine, lysine, tyrosine, phenylalanine, methionine and alanine did not appear to be taken up in appreciable quantities.

When Bacillus anthracis grows in vivo it has properties different from those it has when it grows in vitro (Smith \& Keppie, 1955). This means that the metabolism of the pathogen when growing in the tissues of the host is different from that of the same organism growing in artificial culture. An attempt has therefore been made to study some aspects of the metabolism of this organism when growing in vivo. As the basis for these studies we have had the benefit of the observations of Keppie, Smith \& Harris-Smith (1955) on the final bacteraemia of anthrax in the guinea pig. They showed that, although guinea pigs varied in their initial resistance to infection with $B$. anthracis, once the final bacteraemia had started (c. 10-12 hr. before death) there was a relatively constant growth rate of bacteria in the blood as well as a remarkably constant relationship between bacterial growth and the survival time of the animal. We have made our examination of the metabolism of $B$.anthracis during this final bacteraemia in the guinea pig.

This paper deals with the utilization of amino acids by the pathogen. The object has been to determine changes in the free amino acid content of infected guinea-pig plasma at successive stages of the bacteraemia, and to verify that, as far as possible, recognition of any utilization which might have occurred was not obscured by compensatory mechanisms in the guinea-pig tissues. In an attempt to fulfil the latter condition a number of precautions were taken. Furthermore, it was verified that a similar pattern of utilization occurred when the infected plasma was withdrawn from the guinea pig and incubated in vitro. In many respects this test was adequate but it cannot be relied on absolutely since it is already apparent that the metabolism (though not necessarily the amino acid metabolism) of Bacillus anthracis is different in vivo from that which occurs in vitro.

\section{METHODS}

\section{Collection of samples of plasma from infected guinea pigs at selected stages of the final bacteraemia}

Guinea pigs ( $650 \pm 50$ g.) were infected with Bacillus anthracis strain N.P.; on the third day the terminal bacteraemia was detected and followed during the 
last 10-12 hr. by the methods described by Keppie et al. (1955). The guinea pigs were allowed water but no food during the experiments to minimize fluctuations in their free amino acid pool. During this period the bacterial count rises from approx. $0.2 \times 10^{6}$ chains $/ \mathrm{ml}$. blood to $1 \times 10^{9}$ chains $/ \mathrm{ml}$. in $12 \mathrm{hr}$. It would have been opportune to allow this maximal growth of the organism to take place before taking the final plasma sample, so that the amino acid uptake was as large as possible. However, preliminary experiments showed this to be impossible. Determinations of the total $\alpha$-carboxylamino- $N$ of plasma samples by the method of Woiwod (1949) showed that during the last $3 \mathrm{hr}$. of the bacteraemia a large influx of amino acids into the blood occurred, probably as a result of tissue breakdown; the total amino acid content of the plasma rose four to fivefold. In addition, haemolysis became extensive in the last $3 \mathrm{hr}$. of life. For these reasons the plasma was taken for analysis at an earlier time. It was impossible to obtain from one guinea pig sufficient plasma for subsequent amino acid analysis, so the plasma of two similar guinea pigs was collected and pooled for analysis. Two guinea pigs were selected whose blood had bacterial counts within the range $0.2-0.8 \times 10^{6}$ chains $/ \mathrm{ml}$. Blood $(3 \mathrm{ml}$.) was removed from each animal by cardiac puncture with a fine needle. This was pooled, heparinized (10 i.u. heparin $/ \mathrm{ml}$.) and centrifuged at $150 \mathrm{~g}$ for $30 \mathrm{~min}$. at $0-2^{\circ}$ to remove blood cells. The plasma was sterilized by filtration through Millipore filters and stored at $-15^{\circ}$ until analysed. The two animals were allowed to live and the developing bacteraemia was followed by regular sampling from an ear vein. When the blood contained 1-1.5 $\times 10^{8}$ chains $/ \mathrm{ml}$., $5 \mathrm{ml}$. blood was removed by cardiac puncture and treated as described above. The plasma was centrifuged at $8000 \mathrm{~g}$ for $20 \mathrm{~min}$. at $0-2^{\circ}$ to remove the large numbers of Bacillus anthracis which otherwise would have interfered with filtration.

\section{The parallel growth in vitro of Bacillus anthracis in plasma withdrawn from infected guinea pigs}

Two infected guinea pigs, which had the same bacterial count in the blood $\left(0 \cdot 2-0 \cdot 8 \times 10^{8}\right.$ chains $/ \mathrm{ml}$. $)$ as those used above, were selected. The maximum quantity of blood (c. $12 \mathrm{ml}$.) was removed by cardiac puncture from each animal, heparinized (10 i.u. heparin/ml.), pooled and centrifuged at $150 \mathrm{~g}$ for $30 \mathrm{~min}$. to sediment blood cells. All operations subsequent to removing the blood from the animal were carried out at $37^{\circ}$ and under aseptic conditions. The plasma had the same bacterial content as the whole blood, but only $\mathbf{0 \cdot 3} \%$ and $2 \cdot 0 \%$ of the original red blood cells and white blood cells, respectively. The plasma was treated as follows:

(i) One-quarter of the total volume of plasma was immediately cooled to $4^{\circ}$, sterilized by filtration and stored at $-15^{\circ}$ until required for analysis.

(ii) Half the total volume of plasma was immediately transferred to a warmed Warburg flask and shaken (100 strokes/min.) in a bath at $37^{\circ}$; a slow stream of moist warm air containing $5 \%(\mathrm{v} / \mathrm{v}) \mathrm{CO}_{2}$ was passed over the culture. The growth of the organisms was followed by counting stained smears, prepared as those from guinea pigs, until the total count of cells $/ \mathrm{ml}$. plasma had 
increased to that corresponding to the final count of the guinea-pig blood in the in vivo experiments. In making this comparison, account was taken of the fact that in vitro the mean chain length 7.0 (s.D. 3.8) cells/chain was longer than that in vivo, 4.2 (S.D. 1.6) cells/chain. After the required amount of growth had taken place, the infected plasma was removed from the Warburg flask, cooled rapidly to $4^{\circ}$, centrifuged at $12,000 \mathrm{~g}$ for $20 \mathrm{~min}$. to remove the bulk of the organisms, and filtered through Millipore filter. The filtered plasma was stored at $-15^{\circ}$ until required for analysis.

Under these conditions the growth of the organism occurred at a somewhat slower rate than that observed in vivo and a period of 1-2 $\mathrm{hr}$. longer was needed to attain a similar count. An adequate carbohydrate source was present throughout the growth; determinations of reducing sugar by the method of Hagedorn \& Jensen (1923) as modified by Fujita \& Iwatake (1931) showed that after growth, $60 \%$ of the original blood sugar was still present. The organisms were as capsulated as those growing in vivo but were perhaps less basophilic. In all experiments no contaminants were detected and evaporation from the Warburg vessels was negligible.

(iii) To assess more accurately the change in concentration of amino acids brought about by the growth of the organism, it was necessary to determine the changes produced in the plasma by processes other than those related to the presence of the organism. For this reason, the remaining plasma was freed from bacteria by filtration and incubated in a Warburg flask under the same conditions as for the infected plasma. It was then rapidly cooled and stored at $-15^{\circ}$ until required for analysis. In Table 2 the average percentage change in concentration of each amino acid has been calculated, first (see (a) in Table 2) on the basis of the initial concentration, and secondly (see $(b)$ in Table 2 ) on the basis of the concentration after incubation in the absence of bacteria. It will be noted from Table 2 that with the exception of serine and methionine both calculations yielded similar results.

The rate of liberation of amino acids in this period of incubation was not extensively altered by extracellular processes resulting from the growth of the organism. When some of the plasma, used in (ii) above, was further incubated in the absence of bacteria, the rate of release of individual amino acids was not significantly greater than that shown in Table 2.

\section{Amino acid analysis of plasma}

Removal of protein. This was carried out by the method of Hier \& Bergeim (1945) by using tungstic acid. After addition of the precipitant to the plasma ( $1 \mathrm{ml}$. ), the mixture was allowed to stand at $4^{\circ}$ overnight. The precipitate was removed by centrifugation and the supernatant $(c .3 \mathrm{ml}$.) brought to $\mathrm{pH} 7$ with a trace of dilute $\mathrm{NaOH}$.

Microbiological assays. These were carried out on an ultramicro scale by methods similar to those of Agren (1950). All assays were done in triplicate, the total volume in each tube being $200 \mu \mathrm{l}$. For each assay, a curve was constructed with the results from five dilutions of a standard solution of amino acid. The concentration of each amino acid in a sample equivalent to $33 \mu \mathrm{l}$. 
original plasma (i.e. $100 \mu$ l. of the filtrate after tungstic acid precipitation) was determined.

Methionine, phenylalanine, tyrosine, tryptophan, threonine, serine, glycine and histidine were assayed with Leuconostoc mesenteroides P. 60 in the medium of Henderson \& Snell (1948), and cysteine with the same organism in the medium of Steele, Sauberlich, Reynolds \& Baumann (1949). Valine and lysine were assayed by using Streptococcus faecalis $\mathrm{R}$ again in the medium of Henderson \& Snell and glutamic acid ( + glutamine) with Lactobacillus arabinosus 17-5 in the medium of Dunn, Camien, Rockland, Shankman \& Goldberg (1944). Recoveries of $92-118 \%$ were obtained by these methods when standard quantities of amino acids were added to normal guinea-pig plasma before tungstic acid precipitation.

Paper chromatography. Significant changes in the concentration of leucine + isoleucine, alanine, glutamic acid + glutamine were adequately detected by two-dimensional paper chromatography. After removal of protein, the plasma samples were de-salted in the apparatus of Consden, Gordon \& Martin (1947). The solutions of free amino acids were neutralized with ammonia and evaporated in a vacuum desiccator. Samples, equivalent to $0.25 \mathrm{ml}$. plasma were loaded on to paper chromatograms which were developed in $(a)$ phenol saturated with water; (b) butanol (4 vol.) + acetic acid ( 1 vol.) + water (4 vol.), by the capillary ascent method (Williams \& Kirby, 1948). After evaporation of solvent at room temperature, the chromatograms were sprayed with a ninhydrin solution $(0.2 \%, \mathrm{w} / \mathrm{v}$, ninhydrin in $95 \%, \mathrm{v} / \mathrm{v}$, butanol in water), heated at $95^{\circ}$ for 5 min. and examined visually after standing a further $1 \mathrm{hr}$. at room temperature. It was shown by experiment that under these conditions, a change of $25 \%$ in concentration of the appropriate amino acids could be detected.

Proline estimation. This was carried out by the method of Troll \& Lindsley (1955) on $0.08 \mathrm{ml}$. samples of the deproteinized plasma. An $88 \%$ recovery was obtained by this method when proline was added to normal guinea-pig plasma before tungstic acid precipitation.

A satisfactory method of estimating arginine and aspartic acid in the small samples of plasma available was not obtained and observations on the utilization of these amino acids were not made.

\section{RESULTS}

Table 1 summarizes the results of amino acid analyses before and after in vivo growth of Bacillus anthracis. Clearly glutamine, glycine, threonine and tryptophan were utilized by the pathogen. With the exception of serine, which remained almost unaltered, the concentration of all the other amino acids in the plasma increased. This indicated an influx of amino acids into the blood from the guinea-pig tissues, or hydrolysis of plasma proteins during the course of the experiment, or both. As already mentioned, a gross increase of amino acids was observed during the last $3 \mathrm{hr}$., in guinea pigs dying of anthrax. The greatest increases in concentrations were those of phenylalanine, tyrosine, 
histidine, lysine, alanine and methionine, and it therefore seems probable that these amino acids were not being used appreciably by the pathogen in vivo. Support for this fact comes from a consideration of the changes in concentration of these amino acids brought about by parallel in vitro growth of $B$. anthracis (see Table 2). Here, with the possible exception of methionine, the growth of the pathogen failed to decrease the concentration of these metabolites.

Table 1. Changes in concentration of amino acids in the plasma of infected guinea pigs, produced by growth of Bacillus anthracis

In all experiments the initial and final bacterial counts were within the ranges 1.1$7 \cdot 5 \times 10^{6}$ and $0 \cdot 8-1.2 \times 10^{9}$ cells $/ \mathrm{ml}$. of plasma, respectively.

\begin{tabular}{|c|c|c|c|c|}
\hline \multirow[b]{3}{*}{ Amino acid } & \multicolumn{2}{|c|}{ Conc. $(\mu \mathrm{g} . / \mathrm{ml}$. plasma) } & \multirow{2}{*}{\multicolumn{2}{|c|}{$\begin{array}{l}\text { Average change in conc. as } \\
\% \text { of original conc. }\end{array}$}} \\
\hline & \multirow[b]{2}{*}{ Initially } & \multirow{2}{*}{$\begin{array}{c}\text { After } \\
\text { growth of } \\
\text { B. anthracis }\end{array}$} & & \\
\hline & & & Loss & Increase \\
\hline $\begin{array}{l}\text { Glutamine (plus } \\
\text { glutamic acid) }\end{array}$ & $\begin{array}{l}27 \cdot 3 \\
26 \cdot 4 \\
30 \cdot 6\end{array}$ & $\begin{array}{r}19 \cdot 7 \\
5 \cdot 2 \\
25 \cdot 8\end{array}$ & 40 & - \\
\hline Glutamine & \multicolumn{2}{|c|}{$\begin{array}{l}\text { Paper chromatography } \\
\text { (3 expts.) }\end{array}$} & $>\mathbf{5 0}$ & - \\
\hline Glycine & $\begin{array}{l}32 \cdot 9 \\
26 \cdot 6\end{array}$ & $\begin{array}{l}20 \cdot 9 \\
22 \cdot 5\end{array}$ & 27 & - \\
\hline Threonine & $\begin{array}{l}9 \cdot 8 \\
9 \cdot 6 \\
7 \cdot 8\end{array}$ & $\begin{array}{l}6 \cdot 0 \\
6 \cdot 4 \\
7 \cdot 5\end{array}$ & 27 & - \\
\hline Tryptophan & $\begin{array}{l}7 \cdot 1 \\
8 \cdot 3\end{array}$ & $\begin{array}{l}6 \cdot 0 \\
7 \cdot 1\end{array}$ & 15 & - \\
\hline Serine & $\begin{array}{l}15 \cdot 8 \\
15 \cdot 0\end{array}$ & $\begin{array}{l}15 \cdot 8 \\
15 \cdot 0\end{array}$ & \multicolumn{2}{|c|}{ Same } \\
\hline Proline & $\begin{array}{l}17 \cdot 2 \\
18 \cdot 3\end{array}$ & $\begin{array}{l}19 \cdot 6 \\
21 \cdot 0\end{array}$ & - & 14 \\
\hline Valine & $\begin{array}{l}21 \cdot 3 \\
28 \cdot 8\end{array}$ & $\begin{array}{l}\mathbf{2 6} \cdot 4 \\
\mathbf{3 4} \cdot \mathbf{9}\end{array}$ & - & 22 \\
\hline Glutamic acid & \multicolumn{2}{|c|}{$\begin{array}{l}\text { Paper chromatography } \\
\text { (3 expts.) }\end{array}$} & - & Approx. 25 \\
\hline Leucine + Isoleucine & \multicolumn{2}{|c|}{$\begin{array}{l}\text { Paper chromatography } \\
\text { (4 expts.) }\end{array}$} & \multicolumn{2}{|c|}{ Same to } \\
\hline Cysteine & $\begin{array}{l}4 \cdot 7 \\
6 \cdot 3\end{array}$ & $\begin{array}{l}6 \cdot 9 \\
8 \cdot 7\end{array}$ & 一 & 42 \\
\hline Methionine & $\begin{array}{l}4 \cdot 2 \\
3 \cdot 6 \\
3 \cdot 9\end{array}$ & $\begin{array}{l}\mathbf{6} \cdot 3 \\
6 \cdot 9 \\
3 \cdot 9\end{array}$ & 一 & 46 \\
\hline Alanine & \multicolumn{2}{|c|}{$\begin{array}{l}\text { Paper chromatography } \\
\text { (4 expts.) }\end{array}$} & 一 & $25->50$ \\
\hline Phenylalanine & $\begin{array}{r}9 \cdot 8 \\
12 \cdot 2\end{array}$ & $\begin{array}{l}14 \cdot 7 \\
19 \cdot 6\end{array}$ & - & 55 \\
\hline Histidine & $\begin{array}{l}8 \cdot 5 \\
8 \cdot 3\end{array}$ & $\begin{array}{l}18 \cdot 9 \\
15 \cdot 0\end{array}$ & 一 & 73 \\
\hline Tyrosine & $\begin{array}{l}8 \cdot 8 \\
7 \cdot 8\end{array}$ & $\begin{array}{l}12 \cdot 8 \\
18 \cdot 0\end{array}$ & 一 & 85 \\
\hline Lysine & $\begin{array}{l}9 \cdot 0 \\
9 \cdot 6\end{array}$ & $\begin{array}{l}24 \cdot 6 \\
10 \cdot 5\end{array}$ & - & 145 \\
\hline
\end{tabular}


Table 2. Changes in concentration of amino acids in plasma withdrawn from infected guinea pigs and incubated in vitro

In all experiments the initial and final bacterial counts were within the ranges 2.5$7.5 \times 10^{6}$ and $1.1-1.3 \times 10^{9}$ cells $/ \mathrm{ml}$. plasma, respectively.

\begin{tabular}{|c|c|c|c|c|c|}
\hline \multirow[b]{3}{*}{ Amino acid } & \multicolumn{3}{|c|}{ Conc. $(\mu \mathrm{g} . / \mathrm{ml}$. plasma) } & \multirow{2}{*}{\multicolumn{2}{|c|}{$\begin{array}{l}\text { Average change in conc. as } \\
\% \text { available amino acid }\end{array}$}} \\
\hline & \multirow{2}{*}{$\begin{array}{l}\text { Initial } \\
\quad(a)\end{array}$} & \multirow{2}{*}{$\begin{array}{c}\text { Incubated } \\
\text { in absence } \\
\text { of bacteria } \\
\text { (b) }\end{array}$} & \multirow{2}{*}{$\begin{array}{c}\text { After } \\
\text { growth of } \\
\text { B. anthracis } \\
\text { (c) }\end{array}$} & & \\
\hline & & & & $(a-c)$ & $(b-c)$ \\
\hline $\begin{array}{l}\text { Glutamine (plus } \\
\text { glutamic acid) }\end{array}$ & $\begin{array}{l}16 \cdot 6 \\
29 \cdot 3\end{array}$ & $\begin{array}{l}13 \cdot 6 \\
35 \cdot 8\end{array}$ & $\begin{array}{r}4 \cdot 2 \\
27 \cdot 6\end{array}$ & -31 & -35 \\
\hline Glutamine & \multicolumn{3}{|c|}{ Paper chromatography (5 expts.) } & $-(25-50)$ & $-(0-25)$ \\
\hline Glycine & $\begin{array}{l}26 \cdot 9 \\
30 \cdot 4 \\
28 \cdot 4\end{array}$ & $\begin{array}{l}\mathbf{3 3 \cdot 8} \\
\mathbf{3 1} \cdot 8 \\
\mathbf{3 2} \cdot \mathbf{1}\end{array}$ & $\begin{array}{l}22 \cdot 5 \\
14 \cdot 1 \\
16 \cdot 9\end{array}$ & $-\mathbf{3 8}$ & -45 \\
\hline Threonine & $\begin{array}{l}9 \cdot 0 \\
8 \cdot 6\end{array}$ & $\begin{array}{l}11 \cdot 3 \\
12 \cdot 4\end{array}$ & $\begin{array}{l}4 \cdot 5 \\
6 \cdot 6\end{array}$ & -37 & $-\mathbf{5 3}$ \\
\hline Tryptophan & $\begin{array}{r}18 \cdot 8 \\
10 \cdot 1 \\
7 \cdot 9\end{array}$ & $\begin{array}{l}16 \cdot 4 \\
11 \cdot 3 \\
10 \cdot 4\end{array}$ & $\begin{array}{l}7 \cdot 8 \\
2 \cdot 4 \\
6 \cdot 4\end{array}$ & -48 & -56 \\
\hline Serine & $\begin{array}{r}8 \cdot 3 \\
12 \cdot 8 \\
12 \cdot 3\end{array}$ & $\begin{array}{l}21 \cdot 8 \\
19 \cdot 2 \\
18 \cdot 9\end{array}$ & $\begin{array}{l}10 \cdot 8 \\
15 \cdot 0 \\
10 \cdot 5\end{array}$ & +9 & $-\mathbf{3 9}$ \\
\hline Proline & $\begin{array}{l}13 \cdot 9 \\
21 \cdot 0\end{array}$ & $\begin{array}{l}25 \cdot 8 \\
21 \cdot 3\end{array}$ & $\begin{array}{l}9 \cdot 7 \\
8 \cdot 7\end{array}$ & -47 & -61 \\
\hline Valine & $\begin{array}{l}22 \cdot 5 \\
27 \cdot 0 \\
23 \cdot 3\end{array}$ & $\begin{array}{l}25 \cdot 8 \\
27 \cdot 9 \\
25 \cdot 8\end{array}$ & $\begin{array}{r}10 \cdot 2 \\
8 \cdot 9 \\
0 \cdot 4\end{array}$ & -73 & -75 \\
\hline Glutamic acid & \multicolumn{3}{|c|}{ Paper chromatography (4 expts.) } & -25 & -25 \\
\hline Leucine + Isoleucine & \multicolumn{3}{|c|}{ Paper chromatography (6 expts.) } & $->\mathbf{5 0}$ & $->50$ \\
\hline Cysteine & $\begin{array}{l}6.4 \\
6.9\end{array}$ & $\begin{array}{l}7 \cdot 5 \\
8 \cdot 3\end{array}$ & $\begin{array}{l}5 \cdot 1 \\
6 \cdot 9\end{array}$ & -10 & -24 \\
\hline Methionine & $\begin{array}{l}4 \cdot 3 \\
4 \cdot 8 \\
\mathbf{8 \cdot 2} \\
4 \cdot 5\end{array}$ & $\begin{array}{l}5 \cdot 1 \\
5 \cdot 4 \\
6 \cdot 8 \\
5 \cdot 7\end{array}$ & $\begin{array}{l}4 \cdot 3 \\
4 \cdot 8 \\
3 \cdot 3 \\
6 \cdot 0\end{array}$ & +10 & -20 \\
\hline Alanine & \multicolumn{3}{|c|}{ Paper chromatography (6 expts.) } & Nil & Nil \\
\hline Phenylalanine & $\begin{array}{r}7 \cdot 5 \\
14 \cdot 9 \\
18 \cdot 7 \\
13 \cdot 4\end{array}$ & $\begin{array}{l}10 \cdot 5 \\
16 \cdot 9 \\
21 \cdot 1 \\
15 \cdot 3\end{array}$ & $\begin{array}{l}10 \cdot 5 \\
15 \cdot 2 \\
30 \cdot 7 \\
20 \cdot 4\end{array}$ & +41 & +20 \\
\hline Tyrosine & $\begin{array}{r}7 \cdot 8 \\
8 \cdot 8 \\
12 \cdot 2\end{array}$ & $\begin{array}{l}10 \cdot 0 \\
10 \cdot 6 \\
11 \cdot 3\end{array}$ & $\begin{array}{r}7 \cdot 3 \\
11 \cdot 5 \\
12 \cdot 2\end{array}$ & +8 & -3 \\
\hline Histidine & $\begin{array}{l}10 \cdot 6 \\
18 \cdot 2 \\
15 \cdot 4 \\
14 \cdot 1\end{array}$ & $\begin{array}{l}10 \cdot 0 \\
14 \cdot 6 \\
16 \cdot 7 \\
17 \cdot 4\end{array}$ & $\begin{array}{l}12 \cdot 0 \\
15 \cdot 8 \\
28 \cdot 9 \\
23 \cdot 1\end{array}$ & +26 & +27 \\
\hline Lysine & $\begin{array}{l}12 \cdot 6 \\
10 \cdot 8\end{array}$ & $\begin{array}{l}15 \cdot 0 \\
15 \cdot 6\end{array}$ & $\begin{array}{l}14 \cdot 3 \\
16.5\end{array}$ & +32 & +1 \\
\hline
\end{tabular}


Serine, glutamic acid, and cysteine occupy an intermediate position in both tables, and it is probable therefore that they are used to some extent by Bacillus anthracis growing in vivo. Proline, valine, leucine + isoleucine appear to be more extensively utilized in vitro than in vivo.

\section{DISCUSSION}

It might be expected that Bacillus anthracis, like other Gram-positive organisms, would take up amino acids from its environment during growth. Whether one could detect such uptake, in a complex system such as the 'free' amino acid pool of the blood of animals during the terminal bacteraemic phases of anthrax, would largely depend on the balance between the rate of uptake of individual amino acids and the efficiency of replacement by compensatory host mechanisms. However, the results presented show that a pattern of changes can be observed in the plasma amino acids of infected guinea pigs during the course of the bacteraemia. In view of the results obtained during the parallel growth in vitro it seems reasonable to ascribe these changes to the uptake of metabolites by the invading pathogen. It seems that some amino acids (glutamine, threonine, tryptophan, glycine) are utilized more than others.

It is difficult to relate these results to published work on the in vitro metabolism of Bacillus anthracis except to point out that Thorne (1956) showed glutamine to lie on the pathway of polyglutamic acid synthesis in B. subtilis and in strains of $B$. anthracis. It therefore seems likely that the decrease in concentration of this metabolite observed in vivo may be correlated with the synthesis of capsular polyglutamic acid. The results give no indication of the amino acids which are essential for growth and for the synthesis of virulence-determining factors. The next paper describes the use of antimetabolites in an effort to make a more specific investigation into the requirements for amino acids and other metabolites in these processes.

Our thanks are due to our colleagues Dr J. Keppie and Mrs Patricia W. HarrisSmith for help in the animal experiments and to Mr G. S. Grace for skilled technical assistance.

\section{REFERENCES}

Agren, G. (1950). A micromethod for the microbiological determination of amino acids. Ark. Kemi, 1, 179.

Consden, R., Gordon, A. H. \& Martin, A. J. P. (1947). The identification of lower peptides in complex mixtures. Biochem. J. 41, 590.

Dunn, M. S., Camien, M. N., Rockland, L. B., Shankman, S. \& Goldberg, S. C. (1944). Amino acids, peptides and proteins. XVII. Determination of glutamic acid in protein hydrolysates by a microbiological method. J. biol. Chem. 155, 591.

Fujita, A. \& Iwatake, D. (1931). Determination of true blood sugar without yeast. Biochem. Z. 242, 43.

Hagedorn, H. C. \& Jensen, B. N. (1923). The microdetermination of blood sugar by means of ferricyanide. Biochem. Z. 135, 46.

Henderson, L. M. \& Snell, E. E. (1948). A uniform medium for determination of amino acids with various microorganisms. J. biol. Chem. 172, 15.

Hier, S. W. \& Bergeim, O. (1945). Microbiological determination of free leucine, isoleucine, valine and threonine in dog plasma. J. biol. Chem. 161. 717. 
Keppie, J., Smith, H. \& Harris-Smith, P. W. (1955). The chemical basis of the virulence of Bacillus anthracis. III. The role of the terminal bacteraemia in death of guinea pigs from anthrax. Brit. J. exp. Path. 36, 315.

Smith, H. \& Keppie, J. (1955). In Mechanisms of Microbial Pathogenicity. Symp. Soc. gen. Microbiol. 5, 126.

Steele, B. F., Sauberlich, H. E., Reynolds, M. S. \& Baumann, C. A. (1949). Media for Leuconostoc mesenteroides P. 60 and Leuconostoc citrovorum 8081. J. biol. Chem. 177, 533.

Thorne, C. B. (1956). In Bacterial Anatomy. Symp. Soc. gen. Microbiol. 6, 68.

Troll, W. \& Lindsley, J. (1955). A photometric method for the determination of proline. J. biol. Chem. 215, 655.

Williams, R. J. \& KirBy, H. (1948). Paper chromatography using capillary ascent. Science, 107, 481.

WoIwod, A. J. (1949). A method for the estimation of micro amounts of amino nitrogen and its application to paper partition chromatography. Biochem. J. 45, 412.

(Received 4 July 1957) 